\title{
The Inflorescence and Fruit Peduncle as Indicators of Nitrogen Status of the Avocado Tree
}

\author{
Bruno Razeto and Jorge Salgado \\ Faculty of Agricultural Sciences, University of Chile. Casilla 1004, \\ Santiago, Chile
}

Additional index words. Persea americana Mill., nitrogen fertilization, urea, chemical analysis

\begin{abstract}
A tissue analysis trial for the diagnosis of nitrogen level was performed during the 2001 growing season in Paine County, Metropolitan Region, Chile. Seven-year-old 'Hass' avocado (Persea americana Mill.) trees were soil treated with urea at rates of 0 , 333,666 , and $999 \mathrm{~g} \mathrm{~N} /$ tree, split in two applications ( 2 and 4 months after fruit set). Each treatment was applied to three randomly selected trees. Fifty spring flush leaves and fifteen fruit peduncles were taken per tree 4 months after application. Two months later, 70 panicles per tree were taken, and nitrogen concentration in these samples was determined by Kjeldahl digestion. Differences between treatments were better detected in peduncle and inflorescence samples than in leaf samples. The relationship between nitrogen dose and nitrogen concentration in the tissue was $R^{2}=0.67,0.65$, and 0.56 in peduncle, leaf, and inflorescence, respectively. Consequently, peduncle appears a promising tissue, probably better than leaf, for diagnosing the nitrogen status of avocado trees.
\end{abstract}

Tissues other than the leaf have been mentioned for the nutritional diagnosis of fruit plants. Fregoni (1980) stated that flowers are very useful to study some nutrient deficiencies, mainly boron, in grapevine. A similar statement has been made by Nyomara and Brown (1997) for fruit hull in almond, being the tissue with higher accumulation of boron. According to Montañés et al. (1997) and Sanz et al. (1997), flower analysis could be a useful indicator of the nutritional status, mainly of iron, in peach and other fruit trees. Dulac, cited by Fregoni (1980) found that the cluster stalk represents the response of potassium application to the soil in grapevine better than the leaf. Similarly, Ismail, cited by Fregoni (1980), reports a linear response in nitrogen content of grapevine cluster stalk to increasing doses of nitrogen to the soil.

In a nutritional survey carried out in 14 'Hass' avocado groves growing under different conditions of soil at the Central Zone of Chile, where leaf, inflorescence, fruit peduncle, fruit flesh and seed were analyzed, Granger (2001) found that the inflorescence (panicle) had the highest nitrogen content. She also found that nitrogen concentration in the fruit peduncle showed the greatest variation among groves (Table 1). These results suggested the use of both tissues as promising tools to determine the level of nitrogen supply in this species.

Consequently, the objective of the present trial was to determine the relationship between soil nitrogen fertilization and nitrogen concentration in the leaf, the inflorescence and the fruit peduncle to compare the efficacy of these tissues as nutritional diagnostic tools in avocado trees.

Received for publication 14 Feb. 2003. Accepted for publication 9 Feb. 2004. tree along the closest irrigation furrows. The total dose per tree was split in two application dates (2 Feb. and 31 Mar. 2001), about 2 and 4 months after fruit set.

Representative samples of 50 spring flush leaves and 15 fruit peduncles at early maturity stage ( $8 \%$ oil in the composite sample) were taken around the tree 7 Aug. Samples of 70 determinate panicles per tree were taken at random around the tree 3 Oct., just before bloom at flower stage 10 (Salazar-García et al. (1998). All samples were washed twice with distilled water, dried at $65{ }^{\circ} \mathrm{C}$ for $36 \mathrm{~h}$, and ground in an electric steel mill. Nitrogen concentration was determined by Kjeldahl digestion.

Treatments were laid out in a completely randomized design with four treatments and three single-tree replications per treatment. The experimental unit corresponded to a complete tree. The results were analyzed by analysis of variance and Duncan's multiple range test at the 5\% level. A regression analysis was carried out.

\section{Results and Discussion}

The highest nitrogen concentration was present in the inflorescence, followed by the leaf and then the peduncle, which confirms the results obtained by Razeto and Granger (2001). Nevertheless, the peduncle showed the highest variation coefficient, as a result of a much larger amplitude in the levels of nitrogen in response to fertilizer dose (Table 2). In fact, the highest value in the peduncle was $307 \%$ larger than the lowest one. Whereas in the inflorescence and leaf it was only $72 \%$ and $66 \%$ larger. Furthermore, nitrogen level in the leaf was similar among the treatments, which only differed with the 0 - $\mathrm{N}$ control (Table 2 ). Instead, the peduncle showed differences between the highest and lowest doses, and the inflorescence detected differences even among the highest doses.

These results show the peduncle and inflorescence as being more appropiate tissues than the leaf to find differences among treatments

Table 1. Nitrogen concentration in 'Hass' avocado tissues in 14 groves at the Central Zone of Chile.

\begin{tabular}{lccr}
\hline & \multicolumn{3}{c}{$\mathrm{N} \mathrm{concn}\left(\mathrm{mg} \cdot \mathrm{g}^{-1}\right)$} \\
\cline { 2 - 4 } Parameter & Leaf & Peduncle & Inflorescence \\
\hline Concentration $\left(\mathrm{mg} \cdot \mathrm{g}^{-1}\right)$ & $21.3^{\mathrm{z}}$ & 8.1 & 31.8 \\
$\mathrm{SD}$ & 2.2 & 3.2 & 3.3 \\
$\mathrm{CV}$ & 10.3 & 39.5 & 10.4 \\
\hline
\end{tabular}

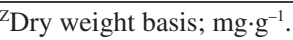

Table 2. Nitrogen concentration in 'Hass' avocado tissues in different nitrogen treatments performed at Paine, Chile.

\begin{tabular}{lccc}
\hline & \multicolumn{3}{c}{$\mathrm{N} \mathrm{concn}\left(\mathrm{mg} \cdot \mathrm{g}^{-1}\right)$} \\
\cline { 2 - 4 } Treatment & Leaf & Peduncle & Inflorescence \\
g Ntree $)$ & 7 Aug. 2001 & 7 Aug. 2001 & 3 Oct. 2001 \\
\hline 0 & $15.3 \mathrm{a}^{\mathrm{z}}$ & $5.1 \mathrm{a}$ & $22.6 \mathrm{a}$ \\
333 & $18.8 \mathrm{~b}$ & $6.8 \mathrm{a}$ & $21.6 \mathrm{a}$ \\
666 & $20.4 \mathrm{~b}$ & $7.8 \mathrm{~b}$ & $25.8 \mathrm{~b}$ \\
999 & $19.4 \mathrm{~b}$ & $11.1 \mathrm{~b}$ & $27.7 \mathrm{c}$ \\
Mean & 18.5 & 7.7 & 24.4 \\
SD & 2.5 & 2.7 & 3.0 \\
CV & 13.3 & 35.6 & 12.3
\end{tabular}

${ }^{\mathrm{z}}$ Dry weight basis. Different letters in the same column indicate significant differences among the treatments means $p \geq 0.05$. 


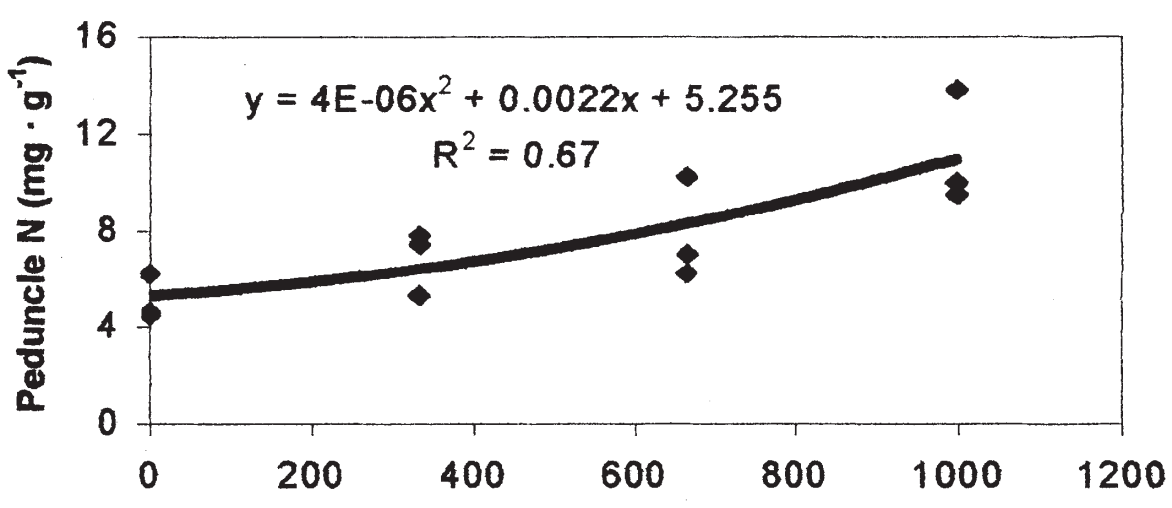

N/tree (g)

Fig. 1. Nitrogen content in 'Hass' avocado peduncle as a result of nitrogen treatments.

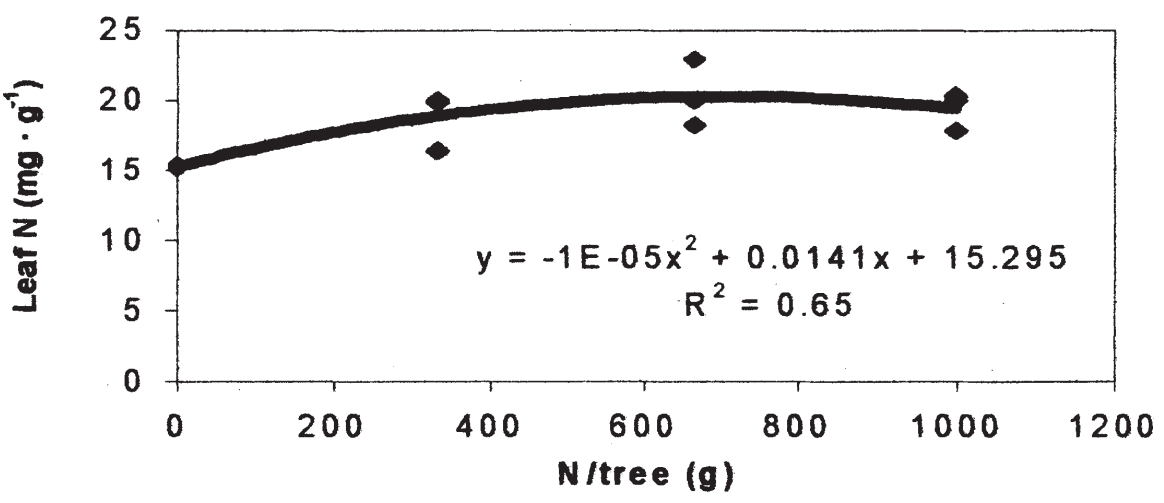

Fig. 2. Nitrogen content in 'Hass' avocado leaves as a result of nitrogen treatments.
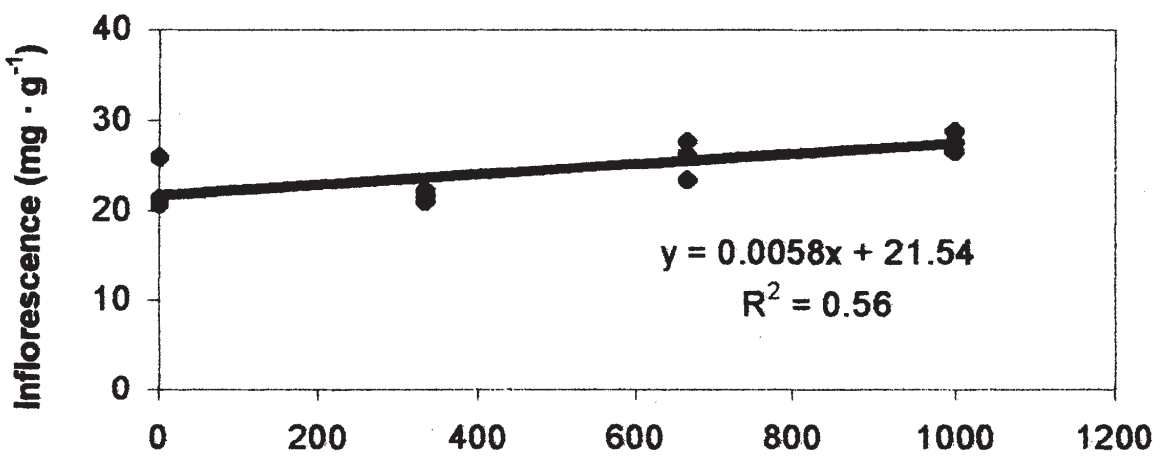

N/tree (g)

Fig. 3. Nitrogen content in 'Hass' avocado inflorescences as a result of nitrogen treatments.

of nitrogen applied to the soil, and confirm previous results of Razeto and Granger (2001) and Granger (2001) in a survey conducted in 14 avocado groves, these tissues appearing as precise for diagnosing of the level of nitrogen and other nutrients in the tree.
The peduncle was the tissue whose nitrogen concentration better correlated with the nitrogen dose applied to the soil $\left(R^{2}=0.67\right.$ against 0.65 for leaf and 0.56 for inflorescence) (Figs. 1-3). This result shows the peduncle as the best indicator of nitrogen level in avocado trees. Furthermore, leaf nitrogen increases to a maximum concentration with the $666 \mathrm{~g} \mathrm{~N}$ per tree dose, decreasing at higher fertilization rates. This particular response indicates that leaf analysis is no longer representative of the $\mathrm{N}$ status at high levels of nitrogen confirming the statement of Weinbaum et al. (1992) to the effect that leaf does not respond to additional nitrogen applications on fruit trees with high nitrogen level. The other tissues analysed in this trial, instead, would be better indicators of this situation of nitrogen in the tree, irrespective of the supply. In fact, nitrogen concentration in the peduncle and the inflorescence kept up according to the dose applied.

Fruit peduncle appears more accurate than the leaf as a tissue to be analyzed to represent the nitrogen level in the avocado tree. In addition, since it does not change position as a result of shoot growth, as does the leaf, it is easier to identify and locate in the tree at sampling. Moreover, tissue mass is large and less exposed to contamination by chemical sprays, dust and other products, that usually deposit on the leaf. The inflorescence, although less than the peduncle, also appears as a promising tissue for diagnosis of the nitrogen status of the tree. This trial is a first approach and additional research should be done, considering yield, in order to obtain more definitive results.

\section{Literature Cited}

Fregoni, M. 1980. Nutrizione e fertilizzazione della vite. Edagricole, Bologna, Italy.

Granger, C. 2001. Análisis químico de flores y frutos para el diagnóstico de la nutrición mineral en palto (Persea americana, Mill.). Memoria de Título, Escuela de Agronomía, Universidad de Chile, Santiago.

Montañés, L., J.Val,A. Betrán, E. Monge, M. Moreno, and M. Montañes. 1997. Floral analysis: fresh and dry weight of flowers from different fruit tree species. Acta Hort. 448:233-240.

Nyomara, A. and P. Brown. 1997. Fall foliar-applied boron increased tissue boron concentration and nut set in almond. J. Amer. Soc. Hort. Sci. 122(3):405-410.

Razeto, B. and C. Granger. 2001. Análisis químico del pedúnculo del fruto y la inflorescencia, posibles herramientas de diagnóstico nutricional en palto (Persea americana Mill.), p. 73. In: Resúmenes. $52^{\circ}$ Congreso Agronómico de Chile, Quillota, Chile.

Salazar-García, S., E. Lord, and C. Lovatt. 1998. Inflorescence and flower development of the "Hass' avocado during "on" and "off" crop years. J. Amer. Soc. Hort. Sci. 123(4):537-544.

Sanz, M., R. Belkhodja, M. Tosselli, L. Montañés, A. Abadía, M. Tagliasini, B. Marangoni, and J. Abadía. 1997. Floral analysis as a possible tool for the prognosis of iron deficiency in peach. Acta Hort. 448:241-246.

Weinbaum, S., R. Johnson, and T. De Jong. 1992. Causes and consequences of overfertilization in orchards. HortTechnology 2:112-121. 